\title{
ARMASIUS IBERIANUS (ORTHOPTERA: TETRIGIDAE: CLADONOTINAE): A NEW GENUS AND SPECIES OF PYGMY GRASSHOPPERS FROM EASTERN CUBA
}

\author{
Daniel E. Perez-Gelabert ${ }^{1}$ and Sheyla Yong ${ }^{2}$ \\ ${ }^{1}$ Integrated Taxonomic Information System (ITIS) and Department of Entomology, United States \\ National Museum of Natural History, Smithsonian Institution, P.O. Box 37012, \\ Washington, DC 20013-7012, USA.perezd@si.edu \\ ${ }^{2}$ Calle 200, No. $3759 / 37$ y 45, C.P 13500, La Lisa, La Habana, Cuba. \\ gruenes@estudiantes.fbio.uh.cu; delliainsulana@gmail.com
}

\begin{abstract}
The new genus and its type species Armasius iberianus, a remarkable cladonotine tetrigid, are described based on a single individual collected from Monte Iberia, Guantánamo Province, in eastern Cuba. Armasius is characterized for having a large pronotum flattened on top to a thin crest that is uniformly elevated only about half the body height, the pronotum covers the whole abdomen, narrowing posteriorly, and turning upwards at its posterior end. A character not yet seen in any other Antillean Cladonotinae is that the posterior angles of the lateral lobes of the pronotum project laterally, flattening to form a horizontal triangular spine.
\end{abstract}

Keywords: Pygmy grasshoppers, Cladonotinae, new genus, new species, Cuba, Antilles.

Título: Armasius iberianus (Orthoptera: Tetrigidae: Cladonotinae): un nuevo género y especie de saltamontes pigmeo del este de Cuba.

\section{RESUMEN}

Se describe el nuevo género y su especie tipo Armasius iberianus, un excepcional tetrígido de la subfamilia Cladonotinae basados en un único ejemplar colectado en el Monte Iberia, Provincia de Guantánamo en la porción oriental de Cuba. Armasius se caracteriza por tener un pronoto grande uniformemente elevado con una cresta comprimida y solo elevada hasta alrededor de la mitad de la altura corporal, el pronoto cubre todo el abdomen y se estrecha posteriormente, su porción posterior elevándose ligeramente. Un carácter todavía no visto en ningún otro Cladonotinae antillano son los ángulos posteriores de los lóbulos laterales del pronoto proyectados hacia los lados, aplanados para formar una espina triangular horizontal.

Palabras clave: saltamontes pigmeos, Cladonotinae, nuevo género, nueva especie, Cuba, Antillas.

\section{INTRODUCTION}

The mountains of the Greater Antilles harbor many endemic taxa that have evolved in unique, secluded environments and consequently have adapted to very specific microclimatic conditions. On Cuba, the largest island of the Greater Antilles, geographic isolation has been an important factor facilitating the evolution of new taxa. Additionally, it is likely that with less intense competition and predation pressures than in the neighboring continental areas the humid mountain environments of the Greater Antilles have functioned as refugia for some animal groups that did not reach the tropical continental areas or later became extinct there.

The Tetrigidae are basal caeliferan Orthoptera distinguished by their small size $(<15 \mathrm{~mm})$, pronotum extended over the head and lack of arolia in the tarsal claws 
(Perez-Gelabert et al., 1998). The most recent world catalogue of Tetrigidae was published by Otte (1997) and included some 1195 species in 11 subfamilies. The Cladonotinae are distinguished by a widely forked frontal costa and for being wingless; this latter feature possibly being an important factor determining their limited dispersal capabilities. Unique and extravagant pronotal morphologies have evolved in the Cladonotinae with many genera having bizarre shapes. The Cladonotinae are mostly an Old World group with relatively few species in the New World. Over 150 species of Cladonotinae have been reported from the Ethiopian and Oriental regions (Otte, 1997), while only three genera and six species are known from South America where other tetrigid subfamilies are predominant (Steinmann, 1969). In contrast to their rarity in the New World, the Cladonotinae appear to be the dominant group of tetrigids in the Greater Antilles. In the last 15 years the West Indian tetrigids have received some taxonomic attention and 12 genera and 14 species have been described all in the subfamily Cladonotinae (Perez-Gelabert et al., 1998; Perez-Gelabert and Otte, 1999; Perez-Gelabert, 2003; 2009), also including one genus and two fossil species from the Miocene Dominican amber (Heads, 2009). A total of 19 of the 24 known Antillean tetrigid species (79\%) plus two fossil species belong in this subfamily (Perez-Gelabert, 2009; Heads, 2009). Although not yet recorded from Puerto Rico, a previously unreported juvenile specimen of Cladonotinae collected near the Guánica forest (southwestern corner of the island), is evidence that they are also found there.

Cuba contains several montane regions, especially in its eastern portion, that include the highest elevation on the island at Pico Turquino $(1,972 \mathrm{~m})$. Although the mountains of Cuba are not very high, most of those mountain forests contain vast areas that are suitable habitat for Cladonotinae. Three genera of Cladonotinae including four species have so far been reported from Cuba: Choriphyllum I. Bolívar with two species that appear to be found in multiple parts of the island, Cubonotus Perez-Gelabert et al. and Cubanotettix Perez-Gelabert et al., each with a single species known only from Pico Turquino in the east.

\section{OBJECTIVE}

- To describe a new genus and species of Cladonotinae from Monte Iberia, Guantánamo province, eastern Cuba.

\section{MATERIAL AND METHODS}

The pinned specimen was studied under $10-60 \mathrm{X}$ magnification and photographed using the Visionary Digital (TM) BK Lab imaging system outfitted with a Canon Mark II 5D. The specimen was directly compared to examples of all other Antillean cladonotine genera. Measurements were taken with an ocular micrometer and are in millimeters.

\section{TAXONOMY \\ Armasius gen. nov. \\ Figures 1-4}

Holotype. Female, from Monte Iberia, Nibujon, III.1972 L. de Armas. Deposited in the entomological collection of the Instituto de Ecología y Sistemática, La Habana, Cuba.

Diagnosis. Distinguished from all other known Antillean Cladonotinae by the unique morphology of the pronotum. The pronotum in Armasius covers nearly the entire body. Although having a small anterior apex, it does not project beyond the head anteriorly, elevating only about half the body height, but having a marked crest that is flattened only on its top portion. The pronotum 
tapers backwards having a posterior end that becomes slightly raised and pointed and reaches the level of the ovipositor. A unique feature of the pronotum is that the posterior angles of the lateral lobes form horizontally flattened triangular spines. This genus may be more similar to Cubonotus Perez-Gelabert et al., 1998, which has a pronotum that is slightly raised with a thick crest but lacking the salient lateral spines.

Diagnosis. Armasius se distingue de todos los demás Cladonotinae antillanos por la morfología única de su pronoto, que cubre casi todo el cuerpo. A pesar de tener un ápice anterior, este no se proyecta mucho más allá de la cabeza, solo elevándose alrededor de la mitad de la altura corporal, pero teniendo una marcada cresta que se aplasta en su porción superior. El pronoto se estrecha posteriormente hasta terminar con una parte que se eleva ligeramente y alcanza el nivel del ovipositor. Un rasgo único del pronoto son los ángulos posteriores de los lóbulos laterales que forman una espina horizontalmente aplastada y triangular.

Etymology. Armasius is an eponym after Dr. Luis F. de Armas (Instituto de Ecología y Sistemática, La Habana, Cuba), a highly accomplished Cuban arachnologist, prolific researcher, author of most of the known Caribbean non-spider arachnids and the collector of this important specimen four decades ago. This name is masculine.

Type species. Armasius iberianus sp. nov.

\section{Armasius iberianus sp. nov.}

Figures 1-4

Diagnosis. This species is distinctive for the unique arquitecture of its pronotum, which is a large crested shield that covers nearly the whole body, the crest being elevated only about half the body height. Also the posterior angles of the lateral lobes forming horizontally flattened triangular spines are unique to this species.

Diagnosis. Esta especie se distingue por la arquitectura única de su pronoto, el cual es un casco crestado que cubre casi todo el cuerpo, la cresta solo elevada alrededor de la mitad de la altura del cuerpo. Los ángulos posteriores de los lóbulos laterales formando espinas aplastadas y triangulares son también únicos a esta especie.

\section{Description}

Coloration. Uniformly dark brown, excepting small areas of lighter brown marking the edges of pronotal lobes and tibiae; edge of pronotal crest somewhat checkered and posterior end of pronotum cream whitish.

Morphology. Body integument granulose typical of cladonotine tetrigids, markedly rugose all over especially in middle of pronotum where large rugosities form prominent bumps.

Head. Small, not elevated above pronotum, only slightly covered by anterior projection of pronotum; vertex not produced, with median carina, about $1.5 \mathrm{X}$ as wide as an eye; frontal costa with rounded rami markedly compressed and protruding from face, more or less continuous with median carina on head vertex. Surface of genae and clypeus very rugose with many lighter colored callosities. Eyes rounded but not very prominent. Ocelli large located at base of frontal costa. Interocular distance about $1.5 \mathrm{X}$ the width of an eye. Small rounded fossae at sides of eyes, surrounded by large callosities. Antennae filiform, probably shorter than the anterior femora (both antennae are missing several articles) with cylindrical segments that vary in size, being over $3 \mathrm{X}$ longer than wide. 

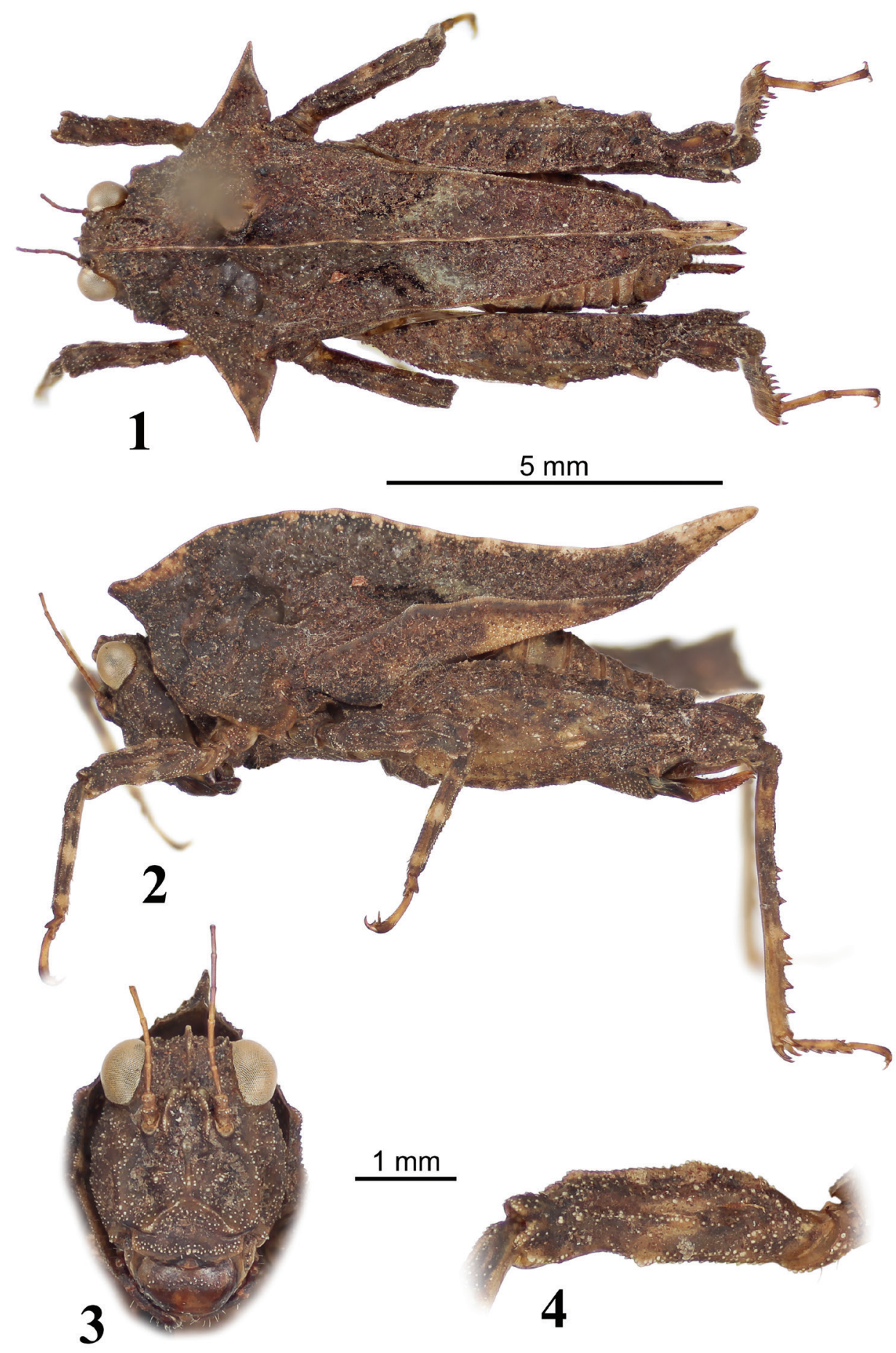
Thorax. Pronotum large in relation to the body, elevated only about half the body height, elongated to cover nearly the entire body length (excepting a small portion of the head and posterior legs); anterior margin with small projection over the head only to level of eyes; medial carina of pronotum elevated throughout its length to form a flattened crest, uniformly elevated, only slightly higher at the level of humeral angles; two small carinulae flanking medial carina at vertex; posterior angles of lateral lobes of pronotum flattening horizontally and markedly projecting laterally from the body to form a flattened triangular lobe at each side that ends in a sharp spine; pronotum elongated posteriorly its width tapering gradually to a fine tip that reaches the level of ovipositor. In side view distal fourth of pronotum elevates slightly pointing upwards at about 45 degrees. Lateral carinae of pronotum prominent with margin serrated, extending from middle of body to point where distal tip starts elevating.

Legs. Anterior femur with flattened and serrated ridge on superior margin; paginal area very rugose having two carinae with a somewhat concave area in between; lower margin of anterior femur with a whitish denticle at anterior end and at middle. Middle femur with one carinae dividing its paginal area, with a whitish denticle at the middle and at posterior end. Posterior femur very rugose with paginal area having five denticular rugosities; whitish denticle on ventral margin and large genicular denticle near knee. Hind tibia with 5 external and 6 internal spines not markedly developed. Third tarsus much smaller than first; pulvilli about equal in length; claws large and symmetrical.

External genitalia. Ovipositor valves each with 4 dorsal and 6 ventral small and rounded teeth. Supragenital plate triangularly elongated.

Measurements. Body length (tip of head to tip of ovipositor) $=10.0 \mathrm{~mm}$, Pronotum length $($ dorsal $)=9.63 \mathrm{~mm}$, Interocular distance $=0.75 \mathrm{~mm}$, Eye diameter $=0.50 \mathrm{~mm}$, Anterior femur length $=2.13 \mathrm{~mm}$, Posterior femur length $=5.63 \mathrm{~mm}$.

Male. Unknown.

Etymology. The species epithet iberianus refers to Monte Iberia, the locality where this tetrigid was collected.

Habitat. Monte Iberia is included within the Parque Nacional Humboldt, a protected area that has been considered among the sites of highest biodiversity in Cuba. Monte Iberia is covered with dense forests that receive rain precipitations of over $1600 \mathrm{~mm}$ annually and the relative humidity is very high. Characteristically the trees of this montane rain forest are covered with mosses, bryophytes and epiphytes. The number of endemic plants and vegetation types in the area has been determined to be very high. A summarized description of the vegetation of these mountains was given by Reyes and Acosta Cantillo (2005). The microhabitat of Armasius is the humid leaf litter covering the forest floor.

\section{Key to the Cladonotinae of Cuba}

1. Body laterally compressed with a foliaceous pronotum......................2

Body not laterally compressed with pronotum not foliaceous....................... 3

2. Highest elevation of pronotum perpendicular to the head.............Choriphyllum sagrai Serville, 1839

Highest elevation of pronotum perpendicular to the middle of body..... 
3. Pointed lateral projection on posterior pronotal lobes present. Armasius iberianus sp. nov.

Pointed lateral projection on posterior pronotal lobes absent 4

4. Pronotum thickly elevated, nearly covering the whole abdomen

Cubonotus altinotatus Perez-Gelabert et al., 1998

Pronotum barely elevated, only covering about half of the abdomen

.Cubanotettix turquinensis Perez-Gelabert et al., 1998.

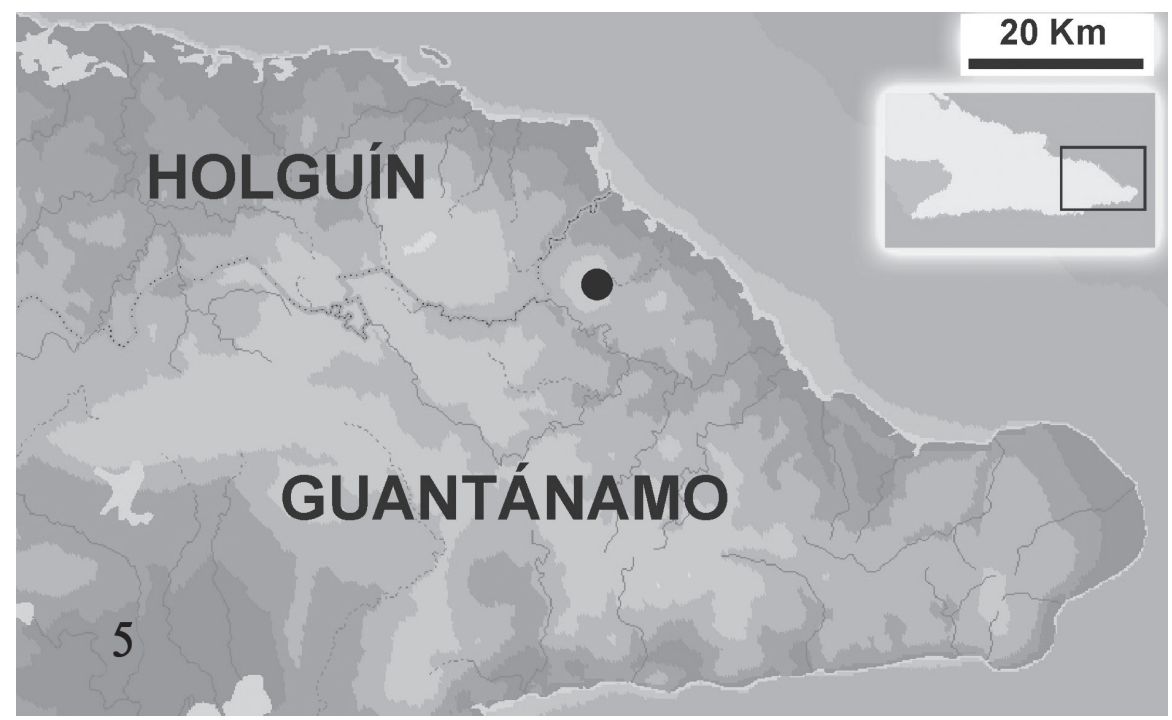

Figure 5. Map showing the geographic location of Monte Iberia in eastern Cuba.

\section{DISCUSSION}

Armasius is the fourth genus of Cladonotinae known from Cuba. It does not closely resemble any other known Antillean Cladonotinae, especially because of the posterior angles of the lateral lobes of the pronotum shaped like flattened spines. Also the general shape of its pronotum, elevated anteriorly to about half its body height and pointed at its posterior end are unique. In contrast the species of Choriphyllum show even more dramatically raised and flattened pronotal crests that cover the whole body to resemble leaves. The pronotum in Cubonotus is more similar to that of Armasius, being slightly raised and becoming laterally compressed only on its top portion. The immature specimen of Cladonotinae collected in Puerto Rico also has a slightly raised pronotum with a more flattened distal portion tapering distally.

The discovery of Armasius in eastern Cuba suggests that additional cladonotines remain to be found in the humid environments of medium-to high-elevations of Cuba and possibly on each of the Antillean islands. The montane forests of Cuba are relatively well-preserved but have never been systematically searched for these small orthopterans. The highest diversity of Cladonotinae within the Antilles still appears to center in the Southern Peninsula of Hispaniola, most of which is in Haitian territory. Six of the 13 known genera are found there (Hottettix, Tiburonotus, Haitianotettix, Bahorucotettix, Antillotettix and Sierratettix). Unfortunately this area has experienced a dramatic reduction of its forest cover with only remnants of its original vegetation found in the most inaccessible mountains. 


\section{ACKNOWLEDGEMENTS}

We are grateful to entomologists Rayner Nuñez and Elba Reyes (Instituto de Ecología y Sistemática, La Habana, Cuba) and Esteban Gutiérrez (Museo Nacional de Historia Natural, La Habana, Cuba) for making possible the visit of DEPG to Cuba and arranging the loan of specimens and export permits. Luis F. de Armas provided comments on the collecting locality. Ted Kahn (ITIS) and Sam Heads (University of Illinois) read the manuscript and provided improvements on the writing.

\section{LITERATURE CITED}

Heads, S. W. 2009. New pygmy grasshoppers in Miocene amber from the Dominican Republic (Orthoptera: Tetrigidae). Denisia 26: 69-74.

Otte, D. 1997. Orthoptera Species File 6. Tetrigoidea and Tridactyloidea (Orthoptera: Caelifera) and Addenda to OSF vols. 1-5. The Orthopterists Society and The Academy of Natural Sciences, Philadelphia.

Perez-Gelabert, D. E. 2003. A new genus and species of tetrigid (Orthoptera: Tetrigidae: Cladonotinae) from Dominican Republic, Hispaniola. Journal of Orthoptera Research 12: 111-114.

Perez-Gelabert, D. E. 2009. Synonymy in Caribbean Tetrigidae (Orthoptera). Proceedings of the Entomological Society of Washington 111: 900-901.

Perez-Gelabert, D. E., B. Hierro and D. Otte. 1998. New genera and species of Greater Antillean grouse-locusts (Orthoptera: Tetrigidae: Cladonotinae). Journal of Orthoptera Research 7: 189-204.

Perez-Gelabert, D. E. and D. Otte. 1999. A new species of Choriphyllum Serville (Orthoptera: Tetrigidae: Cladonotinae) from the Bahamas. Transactions of the American Entomological Society 125: 453-458.

Reyes, O. J. and F. Acosta Cantillo. 2005. Vegetación. In: Fong G., A., D. Maceira F., W. S. Alverson, and T. Wachter, eds. Cuba: Parque Nacional "Alejandro de Humboldt." Rapid Biological Inventories Report 14. The Field Museum, Chicago, pp. 54-69.

Steinmann, H. 1969. The Tetricidae (Orthoptera) of the Neogea. Folia Entomologica Hungarica 22: 383-403.

[Recibido: 20 de abril, 2014. Aceptado para publicación: 29 de julio, 2014] 